\title{
ANALYSIS OF VARIABLES AFFECTING COMPETITIVENESS OF SMES IN THE TEXTILE INDUSTRY
}

\author{
Caner TAÇOĞLU(D) ${ }^{*}$, Cemil CEYLAN (i)2 ${ }^{2}$, Yiğit KAZANÇOĞLU (iD3 \\ 1, 2 Industrial Engineering Department, Istanbul Technical University, Istanbul, Turkey \\ ${ }^{3}$ International Logistics Management Department, Yaşar University, Izmir, Turkey
}

Received 15 January 2018; accepted 27 March 2019

\begin{abstract}
This paper ${ }^{1}$ aims to develop strategy and policy suggestions to increase the competitiveness of SMEs in the textile industry by analyzing the variables that affect competitiveness and contribute to competitiveness literature by adopting a holistic approach to the analysis of competitiveness variables. A hybrid model composed of Delphi and fuzzy DEMATEL (Decision-Making Trial and Evaluation Laboratory) methods were used to gather and analyze the competitiveness variables. This led to the identification of the 15 most important of 73 competitiveness variables relevant to SME competitiveness in the textile industry. These variables were analysed and ranked, and their causal relationships were mapped. The results obtained from the model may function as a reference for SME managers aiming to increase their firm's competitive power.
\end{abstract}

Keywords: SME, competitiveness, management, Delphi, fuzzy DEMATEL, textile industry, production sector.

JEL Classification: L67.

\section{Introduction}

Small and medium-sized enterprises (SMEs) are the major instigators of economic growth in all countries, creating jobs, providing employment opportunities and contributing to large enterprises as suppliers of goods and services. Collectively, SMEs employ the greatest number of employees in a country (Minniti \& Bygrave, 1999). This is also true for Turkey. According to YSHI (Annual Industry and Service Statistics) 2017 results, SMEs in Turkey accounted for $75.8 \%$ of employment, $55 \%$ of salaries and wages, and $65.5 \%$ of GDP. SMEs in Turkey formed $99.9 \%$ of the total number of enterprises in 2017.

The majority of SMEs are simple organizations with flexibility and a short decision chain. Their understanding of customer needs and procedures allows them to have a quick response

\footnotetext{
1 This article is derived from the PhD thesis of Caner Taçoğlu.
}

*Corresponding author. E-mail: caner.tacoglu@ieu.edu.tr 
to the customers. Despite these supportive features of SMEs, they are under great pressure to maintain their competitiveness in domestic and international markets (Singh, Garg, \& Deshmukh, 2008). In the production sector, lack of product characteristics provided by SMEs can negatively affect the competitive power of large enterprises. Large companies therefore prefer to collaborate with SMEs that have competitive power. Competitive paradigms are constantly changing due to rapid technological developments, the unstable needs of consumers and the unpredictable environment. These changes have created a challenging competitive setting in the areas of pricing, quality, time and innovation (Lorsuwanrat, 2010). Acquiring knowledge and knowledge management has become crucial (Fang, Wang, \& Chen, 2017; Zhou, Kautonen, H. Wang, \& L. Wang, 2017). For this reason, it is imperative for SMEs to create flexible business strategies in order to survive in the market.

SME owners and managers have begun to focus on firm competencies and human resources management, in particular by attracting valuable employees to the organization and turning them into a competitive advantage. However, today, it is not always possible for SMEs to focus on a small number of competencies to gain competitive advantage. SMEs should therefore make efforts to gain competitive advantage in multiple areas, such as product, manufacturing, design, distribution, communication, marketing, management, human resources, R\&D and focus as much as possible on the criteria that increase competitive power. For continuous improvement, it is important that SMEs measure themselves against the very best in the sector (Singh et al., 2008).

The competitiveness literature generally focusses on macro environments such as countries, cities or industries. Few studies focus on firm level analysis, therefore there is a need for papers that analyse the competitiveness of small businesses (Szerb \& Ulbert, 2009; Cetindamar \& Kilitcioglu, 2013). There is still no consensus in the competitiveness literature relating to the factors affecting competitiveness and the importance of these factors (Sirikrai \& Tang, 2006). Scholars have studied the SME competitiveness in the isolation of certain competitiveness aspects, generating a gap of holistic approach to analyse the competitiveness of SME's (Singh et al., 2008). This study addresses the above issues by focusing on SME competitiveness, taking a holistic approach to the identification and analysis of the variables that affect competitiveness. The proposed method in this study has the capability to reveal not only the importance levels, but also the causal relationship among the variables.

Although systems theory in management studies is undoubtedly of great complexity, it promotes a better awareness of complex situations and increase the likelihood of taking appropriate actions (Kast \& Rosenzweig, 1972). We believe using systems theory to analyse SME competitiveness is more likely to yield results that are practically applicable for managers, thus we gather all competitiveness variables and analyse them holistically. Understanding the interactions of each element is extremely important when using the systems theory, therefore a key issue is selecting an appropriate methodology. We use a hybrid methodology to discover the importance levels and causal relationships of each variable for this purpose. The hybrid methodology is composed of the popular Delphi and fuzzy DEMATEL (DecisionMaking Trial and Evaluation Laboratory) methods. In addition to a specially modified classic Delphi method, fuzzy DEMATEL method is integrated into the last phase of Delphi. Delphi is used to reveal the most important variables and fuzzy DEMATEL to examine the causal 
relationships of variables fulfilling the systems theory requirements.

Ensuring competitive advantage for SMEs in the textile industry requires an analysis of the relevant competitiveness variables. For this reason, a competitiveness variable pool was created which, to the best of our knowledge, was not previously done for SMEs, and then filtered by experts in the relevant field via the first phase of the proposed model. In the second phase, the importance of selected variables was analyzed. Finally, causal relations for the most important variables were identified and ranked using fuzzy DEMATEL. The findings may support SME managers in making strategic decisions, and thus increase their organizations' competitiveness levels. This paper aims to make a significant contribution to competitiveness literature by identifying the importance levels of the variables relevant to SME competitiveness in the textile industry, conducting a relationship analysis and providing SME managers with guidance on the development of competitiveness improvement policies. The hybrid model presented in the study can be used as a framework for future studies aimed at analyzing competitiveness of SMEs in different sectors.

This paper is arranged as follows: competitiveness variable pool is presented in section 1 by reviewing the literature on SME competitiveness and variables that affect competitiveness. Section 2 introduces the proposed hybrid model in the paper. In section 3, the methods used in the study are explained and details of the proposed hybrid model are given. Application of the hybrid model, data analysis and the results are displayed in Section 4 . The causal relation diagram and the results of the proposed model are also discussed in section 4. Subsequently, the concluding remarks, limitations and future studies are presented in Conclusions Section.

\section{The SME competitiveness variable pool}

An extensive and systematic literature research was conducted to obtain the variables that affect competitiveness in production SME's. Three types of sources for finding these variables were examined: (1) papers that analyze the impact of selected firm characteristics on competitiveness, (2) papers that measure SME competitiveness and professional competitiveness indexes, (3) papers that investigate the relationship between competitiveness strategies (i.e. Porter's generic strategies) and various firm characteristics. These papers label the variables as strategy variables, competitiveness variables or business performance variables. However, regardless of their label, all of them affect competitiveness.

Previous studies in the competitiveness literature focused on specific competitiveness areas in isolation and derived the competitiveness variables accordingly. Some of the specific areas that are present in the literature are innovation and competitiveness (Salavou, Baltas, \& Lioukas, 2004), supply chain competitiveness (Joshi, Nepal, Rathore, \& Sharma, 2013), learning orientation and competitiveness (Calantone, Cavusgil, \& Zhao, 2002), marketing strategies and competitiveness (Siu, Fang, \& Lin, 2004), knowledge management and competitiveness (Perez \& Pablos, 2003), information technology and competitiveness (Lai, Zhao, \& Wang, 2006). It is indubitable that these studies provide valuable insight to competitiveness literature by analysing the chosen variables on firm competitiveness. However, we believe that, in addition to these area-specific approaches, it is also crucial to be able to analyse the entire range of variables that affect firm competitiveness, deducting a holistic outcome that 
can be invaluable for both scholars and practitioners.

The main SME firm characteristics in relevant literature are categorized as production, innovation, marketing, organizational learning, information technology, knowledge management, human resources, entrepreneurship, management, finance and firm competencies. All of the variables previously studied were added to the competitiveness variable pool. For instance, studies that focus on the production aspect of SME competitiveness generally analyze the four most common variables: cost, quality, flexibility and delivery. Two further variables, product design and product service, were studied less frequently, however, in this study these were added to the competitiveness variable pool.

Competitiveness variable pool is compiled not only from academic articles, but also the competitiveness indexes created by professional companies or worldwide organizations. The main examples are the World Economic Forum's Global Competitiveness Index (GCI), and the International Trade Center's work on SME competitiveness. However, since these global indexes measure competitiveness among countries, the majority of these variables are not relevant to SMEs.

In the broad competitiveness literature, Porter's competitiveness strategies play an important role. Many publications offer the relationship analysis of Porter's generic strategies and firm performance (Yamin, Mavondo, Gunasekaran, \& Sarros, 1997; Powers \& Hahn, 2004; Kim, Nam, \& Stimpert, 2004; Acquaah \& Yasai-Ardekani, 2008; Pertusa-Ortega, MolinaAzorín, \& Claver-Cortés, 2009), marketing strategy (Wu, Lin, \& Lee, 2010), organizational learning (Wanto \& Suryasaputra, 2012), entrepreneurship (Linton \& Kask, 2017) and innovation (Bayraktar, Hancerliogullari, Cetinguc, \& Calisir, 2017). The variables that measure different characteristics affecting firm competitiveness were specifically chosen as candidates for the competitiveness variable pool.

As a result of this extensive and systematic literature research, a total of 73 variables were accumulated in the competitiveness variable pool. These variables however, needed to be filtered to eliminate duplicates, and to merge those with overlapping meanings. The filtering of the raw competitiveness variable pool through the proposed method in this study yielded 60 unique competitiveness variables shown in Table 1. This is the original SME competitiveness variable pool.

Table 1. The SME competitiveness variable pool

\begin{tabular}{|l|l|}
\hline $\begin{array}{c}\text { Competitiveness } \\
\text { Variable }\end{array}$ & \multicolumn{1}{|c|}{ Reference } \\
\hline Product Innovation & $\begin{array}{l}\text { Yamin et al. (1997), Calantone et al. (2002), Arago'n-Correa, García-Morales, } \\
\text { and Cordón-Pozo (2007), Ziegler and Nogareda (2009), Jiménez-Jiménez } \\
\text { and Sanz-Valle (2011), García-Morales, Jiménez-Barrionuevo, and Gutiérrez- } \\
\text { Gutiérrez (2012), Ollo-López and Aramendía-Muneta (2012), Song (2015), } \\
\text { Bayraktar et al. (2017), Wattanapruttipaisan (2002), Gál (2010), Sirikrai and } \\
\text { Tang (2006), Szerb and Ulbert (2009), Singh et al. (2008) }\end{array}$ \\
\hline Process Innovation & $\begin{array}{l}\text { Yamin et al. (1997), Ziegler and Nogareda (2009), Jiménez-Jiménez and } \\
\text { Sanz-Valle (2011), García-Morales et al. (2012), Ollo-López and Aramendía- } \\
\text { Muneta (2012), Bayraktar et al. (2017), Sirikrai and Tang (2006), Singh et al. } \\
\text { (2008) }\end{array}$ \\
\hline
\end{tabular}


Continued Table 1

\begin{tabular}{|c|c|}
\hline $\begin{array}{l}\text { Competitiveness } \\
\text { Variable }\end{array}$ & Reference \\
\hline Risk Taking & $\begin{array}{l}\text { Calantone et al. (2002), Arago'n-Correa et al. (2007), Song (2015), Bayraktar } \\
\text { et al. (2017), Wattanapruttipaisan (2002), Sirikrai and Tang (2006) }\end{array}$ \\
\hline Proactiveness & $\begin{array}{l}\text { Calantone et al. (2002), Arago'n-Correa et al. (2007), Song (2015), Bayraktar } \\
\text { et al. (2017) }\end{array}$ \\
\hline $\begin{array}{l}\text { Administrative } \\
\text { Innovation }\end{array}$ & $\begin{array}{l}\text { Yamin et al. (1997), Jiménez-Jiménez and Sanz-Valle (2011), García-Morales } \\
\text { et al. (2012) }\end{array}$ \\
\hline Invesment for $\mathrm{R} \& \mathrm{D}$ & Wattanapruttipaisan (2002), Gál (2010) \\
\hline Product Cost & $\begin{array}{l}\text { Miller and Roth (1994), Sweeney and Szwejczewski (1996), Avella, Fernandez, } \\
\text { and Vazquez (1998), Kathuria (2000), Frohlich and Dixon (2001), Zhao et al. } \\
\text { (2006), Cagliano, Acur, and Boer (2005), Rose, Kumar, and Ibrahim (2008), } \\
\text { Tian, Jia, and Malik (2010), Joshi et al. (2013), Gál (2010), Sirikrai and Tang } \\
\text { (2006), Szerb and Ulbert (2009), Guzmán et al. (2012) }\end{array}$ \\
\hline Product Quality & $\begin{array}{l}\text { Miller and Roth (1994), Sweeney and Szwejczewski (1996), Avella et al. } \\
\text { (1998), Kathuria (2000), Frohlich and Dixon (2001), Zhao et al. (2006), } \\
\text { Cagliano et al. (2005), Rose et al. (2008), Tian et al. (2010), Joshi et al. (2013), } \\
\text { Wattanapruttipaisan (2002), Gál (2010), Sirikrai and Tang (2006) }\end{array}$ \\
\hline Product Flexibility & $\begin{array}{l}\text { Miller and Roth (1994), Sweeney and Szwejczewski (1996), Avella et al. } \\
\text { (1998), Kathuria (2000), Frohlich and Dixon (2001), Zhao et al. (2006), } \\
\text { Cagliano et al. (2005), Rose et al. (2008), Tian et al. (2010), Joshi et al. (2013), } \\
\text { Gál (2010) }\end{array}$ \\
\hline Product Delivery & $\begin{array}{l}\text { Miller and Roth (1994), Sweeney and Szwejczewski (1996), Avella et al. } \\
\text { (1998), Kathuria (2000), Frohlich and Dixon (2001), Zhao et al. (2006), } \\
\text { Cagliano et al. (2005), Rose et al. (2008), Tian et al. (2010), Joshi et al. (2013), } \\
\text { Wattanapruttipaisan (2002), Gál (2010), Sirikrai and Tang (2006) }\end{array}$ \\
\hline Product Design & $\begin{array}{l}\text { Miller and Roth (1994), Sweeney and Szwejczewski (1996), Avella et al. } \\
\text { (1998), Kathuria (2000), Frohlich and Dixon (2001), Zhao et al. (2006), Tian } \\
\text { et al. (2010) }\end{array}$ \\
\hline Product Service & $\begin{array}{l}\text { Miller and Roth (1994), Avella et al. (1998), Kathuria (2000), Zhao et al. } \\
\text { (2006), Cagliano et al. (2005), Tian et al. (2010), Wattanapruttipaisan (2002), } \\
\text { Gál (2010) }\end{array}$ \\
\hline Green Products & Tian et al. (2010) \\
\hline $\begin{array}{l}\text { Usage of Produc- } \\
\text { tion Capacity }\end{array}$ & Wattanapruttipaisan (2002) \\
\hline $\begin{array}{l}\text { Knowledge } \\
\text { Acquisition }\end{array}$ & $\begin{array}{l}\text { Bontis, Crossan, and Hulland (2002), Perez Lopez et al. (2005), Arago'n- } \\
\text { Correa et al. (2007), Jiménez-Jiménez and Sanz-Valle (2011), García-Morales } \\
\text { et al. (2012), Santos-Vijande et al. (2012), Song (2015), Singh et al. (2008), } \\
\text { Carneiro (2000), Perez and Pablos (2003) }\end{array}$ \\
\hline $\begin{array}{l}\text { Knowledge } \\
\text { Dissemination }\end{array}$ & $\begin{array}{l}\text { Calantone et al. (2002), Bontis et al. (2002), Perez Lopez et al. (2005), } \\
\text { Arago'n-Correa et al. (2007), Yeo (2007), Jiménez-Jiménez and Sanz-Valle } \\
\text { (2011), García-Morales et al. (2012), Santos-Vijande et al. (2012), Song (2015), } \\
\text { Szerb and Ulbert (2009), Singh et al. (2008) }\end{array}$ \\
\hline $\begin{array}{l}\text { Shared } \\
\text { Interpretation }\end{array}$ & $\begin{array}{l}\text { Calantone et al. (2002), Bontis et al. (2002), Perez Lopez et al. (2005), } \\
\text { Arago'n-Correa et al. (2007), Yeo (2007), Jiménez-Jiménez and Sanz-Valle } \\
\text { (2011), García-Morales et al. (2012), Wanto and Suryasaputra (2012), Santos- } \\
\text { Vijande et al. (2012), Song (2015), Singh et al. (2008) }\end{array}$ \\
\hline
\end{tabular}


Continued Table 1

\begin{tabular}{|c|c|}
\hline $\begin{array}{l}\text { Competitiveness } \\
\text { Variable }\end{array}$ & Reference \\
\hline $\begin{array}{l}\text { Organizational } \\
\text { Memory }\end{array}$ & $\begin{array}{l}\text { Perez Lopez et al. (2005), Jiménez-Jiménez and Sanz-Valle (2011), Santos- } \\
\text { Vijande et al. (2012), Song (2015) }\end{array}$ \\
\hline $\begin{array}{l}\text { Adaptability to } \\
\text { Change }\end{array}$ & Wattanapruttipaisan (2002), Gál (2010), Singh et al. (2008) \\
\hline Open-mindedness & Calantone et al. (2002), Bontis et al. (2002), Wattanapruttipaisan (2002) \\
\hline Employee Skills & $\begin{array}{l}\text { Arago'n-Correa et al. (2007), García-Morales et al. (2012), Wanto and } \\
\text { Suryasaputra (2012), Wattanapruttipaisan (2002), Gál (2010), Sirikrai and } \\
\text { Tang (2006), Singh et al. (2008), Carneiro (2000) }\end{array}$ \\
\hline Product Pricing & $\begin{array}{l}\text { Leonidou, Katsikeas, and Samiee (2002), Rundh (2003), Gonzalez et al. } \\
\text { (2004), Siu et al. (2004), Rhee and Mehra (2006), L. C. Leonidou, C. N. } \\
\text { Leonidou, Fotiadis, and Zeriti (2013), Martin, Javalgi, and Cavusgil (2017), } \\
\text { Chari, Balabanis, Robson, and Slater (2017), Wattanapruttipaisan (2002), Gál } \\
\text { (2010) }\end{array}$ \\
\hline $\begin{array}{l}\text { Product } \\
\text { Distribution }\end{array}$ & $\begin{array}{l}\text { Leonidou et al. (2002), Rundh (2003), Gonzalez et al. (2004), Siu et al. (2004), } \\
\text { Rhee and Mehra (2006), Leonidou et al. (2013), Martin et al. (2017), Chari et } \\
\text { al. (2017) }\end{array}$ \\
\hline Product Promotion & $\begin{array}{l}\text { Leonidou et al. (2002), Gonzalez et al. (2004), Siu et al. (2004), Rhee and } \\
\text { Mehra (2006), Leonidou et al. (2013), Martin et al. (2017), Chari et al. (2017), } \\
\text { Gál (2010) }\end{array}$ \\
\hline $\begin{array}{l}\text { Product } \\
\text { Advertising }\end{array}$ & $\begin{array}{l}\text { Leonidou et al. (2002), Siu et al. (2004), Martin et al. (2017), Chari et al. } \\
\text { (2017) }\end{array}$ \\
\hline $\begin{array}{l}\text { Communication } \\
\text { with Customers }\end{array}$ & $\begin{array}{l}\text { Rundh (2003), Leonidou et al. (2013), Martin et al. (2017), Chari et al. (2017), } \\
\text { Gál (2010) }\end{array}$ \\
\hline $\begin{array}{l}\text { Customer } \\
\text { Satisfaction }\end{array}$ & Wattanapruttipaisan (2002), Gál (2010) \\
\hline $\begin{array}{l}\text { Degree of Custo- } \\
\text { mer Orientation }\end{array}$ & Global Competitiveness Index, Wattanapruttipaisan (2002) \\
\hline Firm Service & Leonidou et al. (2002), Martin et al. (2016), Chari et al. (2017) \\
\hline $\begin{array}{l}\text { Technological } \\
\text { Infrastructure }\end{array}$ & $\begin{array}{l}\text { Melville et al. (2004), Bhatt and Grover (2005), Kalkan et al. (2011), Cohen } \\
\text { and Olsen (2013), Mao et al. (2016), Gál (2010) }\end{array}$ \\
\hline $\begin{array}{l}\text { Use of Information } \\
\text { Technology }\end{array}$ & $\begin{array}{l}\text { Powell and Dent-Micallef (1997), Melville et al. (2004), Kalkan et al. (2011), } \\
\text { Chao and Chandra (2012), Mandal and Bagchi (2016), Sirikrai and Tang } \\
\text { (2006), Singh et al. (2008) }\end{array}$ \\
\hline $\begin{array}{l}\text { Management } \\
\text { of Information } \\
\text { Technology }\end{array}$ & $\begin{array}{l}\text { Powell and Dent-Micallef (1997), Melville et al. (2004), Lai et al. (2006), } \\
\text { Kalkan et al. (2011), Cohen and Olsen (2013), Mao et al. (2016), Mandal and } \\
\text { Bagchi (2016), Wattanapruttipaisan (2002), Singh et al. (2008) }\end{array}$ \\
\hline $\begin{array}{l}\text { Availability of } \\
\text { Latest Technologies }\end{array}$ & $\begin{array}{l}\text { Global Competitiveness Index (2017), Wattanapruttipaisan (2002), Gál (2010), } \\
\text { Sirikrai and Tang (2006), Szerb and Ulbert (2009), Singh et al. (2008) }\end{array}$ \\
\hline $\begin{array}{l}\text { Creating Valuable } \\
\text { Information }\end{array}$ & Carneiro (2000), Perez and Pablos (2003) \\
\hline $\begin{array}{l}\text { Knowledge } \\
\text { Transfer }\end{array}$ & Carneiro (2000), Perez and Pablos (2003) \\
\hline Intellectual Capital & Carneiro (2000), Perez and Pablos (2003) \\
\hline $\begin{array}{l}\text { Continous Educa- } \\
\text { tion and Training }\end{array}$ & $\begin{array}{l}\text { Intracen SME Competitiveness Grid (2016), Wattanapruttipaisan (2002), Gál } \\
\text { (2010), Szerb and Ulbert (2009) }\end{array}$ \\
\hline
\end{tabular}


End of Table 1

\begin{tabular}{|c|c|}
\hline $\begin{array}{l}\text { Competitiveness } \\
\text { Variable }\end{array}$ & Reference \\
\hline $\begin{array}{l}\text { Performance } \\
\text { Management }\end{array}$ & Wattanapruttipaisan (2002), Resurreccion (2012) \\
\hline $\begin{array}{l}\text { Career } \\
\text { Management }\end{array}$ & Wattanapruttipaisan (2002) \\
\hline $\begin{array}{l}\text { Communication } \\
\text { with Employees }\end{array}$ & Wattanapruttipaisan (2002), Resurreccion (2012) \\
\hline $\begin{array}{l}\text { Employee } \\
\text { Motivation }\end{array}$ & Singh et al. (2008), Carneiro (2000) \\
\hline $\begin{array}{l}\text { Ethical Behaviour } \\
\text { of Firms }\end{array}$ & Global Competitiveness Index (2017), Gál (2010) \\
\hline $\begin{array}{l}\text { Employee's Tertiary } \\
\text { Education Ratio }\end{array}$ & Global Competitiveness Index (2017) \\
\hline Employee Benefits & Resurreccion (2012) \\
\hline Market Share & $\begin{array}{l}\text { Wattanapruttipaisan (2002), Gál (2010), Sirikrai and Tang (2006), Szerb and } \\
\text { Ulbert (2009), Guzmán et al. (2012) }\end{array}$ \\
\hline Increase in Sales & Wattanapruttipaisan (2002), Sirikrai and Tang (2006) \\
\hline $\begin{array}{l}\text { Return on Assets } \\
\text { (ROA) }\end{array}$ & Wattanapruttipaisan (2002), Gál (2010) \\
\hline $\begin{array}{l}\text { Return on Equity } \\
\text { (ROE) }\end{array}$ & Gál (2010) \\
\hline $\begin{array}{l}\text { Return on } \\
\text { Invesment (ROI) }\end{array}$ & Wattanapruttipaisan (2002), Gál (2010) \\
\hline $\begin{array}{l}\text { Audited Financial } \\
\text { Statement }\end{array}$ & Intracen SME Competitiveness Grid (2016), Wattanapruttipaisan (2002) \\
\hline $\begin{array}{l}\text { Return on Sales } \\
\text { (ROS) }\end{array}$ & Sirikrai and Tang (2006), Guzmán et al. (2012) \\
\hline $\begin{array}{l}\text { Manager's } \\
\text { Experience }\end{array}$ & Intracen SME Competitiveness Grid (2016), Wattanapruttipaisan (2002) \\
\hline $\begin{array}{l}\text { Top Management } \\
\text { Support }\end{array}$ & Singh et al. (2008) \\
\hline $\begin{array}{l}\text { Professional } \\
\text { Management }\end{array}$ & $\begin{array}{l}\text { Global Competitiveness Index (2017), Wattanapruttipaisan (2002), Sirikrai } \\
\text { and Tang (2006), Szerb and Ulbert (2009) }\end{array}$ \\
\hline Strategic Alliance & Street and Cameron (2007), Szerb and Ulbert (2009), Singh et al. (2008) \\
\hline Manager Attributes & Wattanapruttipaisan (2002), Singh et al. (2008) \\
\hline $\begin{array}{l}\text { Total Quality } \\
\text { Management }\end{array}$ & Wattanapruttipaisan (2002), Singh et al. (2008) \\
\hline $\begin{array}{l}\text { International } \\
\text { Quality Certificate }\end{array}$ & $\begin{array}{l}\text { Intracen SME Competitiveness Grid (2016), Wattanapruttipaisan (2002), } \\
\text { Sirikrai and Tang (2006) }\end{array}$ \\
\hline $\begin{array}{l}\text { University-Industry } \\
\text { Collobration } \\
\text { Projects }\end{array}$ & Global Competitiveness Index (2017) \\
\hline $\begin{array}{l}\text { Company } \\
\text { Ownership of } \\
\text { Patents }\end{array}$ & Global Competitiveness Index (2017), Gál (2010), Guzmán et al. (2012) \\
\hline
\end{tabular}




\section{Proposed hybrid model}

The hybrid model is composed of three elements, competitiveness variable pool (Table 1), Delphi method, and fuzzy DEMATEL method. Competitiveness variable pool was created based on literature research and expert knowledge. Delphi uses expert knowledge to assess the importance levels, and fuzzy DEMATEL uses expert knowledge to identify the causal relationships between variables. The interaction of variables and their importance levels provide SME managers with crucial information. The hybrid model requires a set of experts in the relevant sector, whose knowledge can be generalized to the selected sector and all other SME managers may benefit from the results of the study.

The fuzzy DEMATEL method is integrated into a modified version of the Delphi method. There is a dataflow between Delphi and fuzzy DEMATEL methods which operate together to produce a shared result. Third phase of Delphi method is composed of fuzzy DEMATEL, and Delphi results of the second phase serve as an input to fuzzy DEMATEL; thus, we call it a hybrid model. In the proposed hybrid model (Table 2), the three-phased Delphi outline, presented by Schmidt, Lyytinen, Keil, and Cule (2001), has been modified.

Table 2. Outline of the proposed hybrid model

\begin{tabular}{|l|l|}
\hline $\begin{array}{l}\text { Phase 1: } \\
\text { Literature Review \& Brainstorming }\end{array}$ & $\begin{array}{l}\text { - Create competitiveness variable pool } \\
- \text { Filter the pool }\end{array}$ \\
\hline $\begin{array}{l}\text { Phase 2: } \\
\text { Narrowing Down }\end{array}$ & - Gather the most important variables \\
\hline $\begin{array}{l}\text { Phase 3: } \\
\text { Relationship Analysis \& Ranking }\end{array}$ & $\begin{array}{l}\text { - Apply fuzzy DEMATEL to the most important } \\
\text { variables }\end{array}$ \\
\hline
\end{tabular}

The proposed hybrid model enables the researchers to explore and analyze the variables that affect SME competitiveness. The SME competitiveness literature currently lacks a systematic, simple holistic framework for the investigation of these variables. Such a framework has been established in this study as the proposed hybrid model. Empirical application of the model reveals the importance levels of competitiveness variables, displays their causal interactions and presents a guide to SME managers for the development of competitiveness improvement policies. The hybrid model proposed in the study can be used as a framework for future analyses of competitiveness of SMEs on different production industries. The basic flow diagram of the proposed hybrid model is presented in Figure 1. At the end of the second round of Delphi study for phase 1, the competitiveness variable pool (Table 1) was completed.

DEMATEL was chosen among other MCDM (multiple criteria decision making) methods due to the appropriacy of properties for the purpose of this study. The DEMATEL method supports proposed systems theory approach via forming a structural model to visualize the causal relationship of sub-systems through a causal diagram. DEMATEL also identifies the interaction of each competitiveness variable. The aim is to produce results that can provide effective guidance for SME managers, therefore it is essential to allow visualization of the causal relationships of the competitiveness variables. Using precise numerical values for human judgment may be misleading, fuzzy logic is therefore essential in analysing the issues 


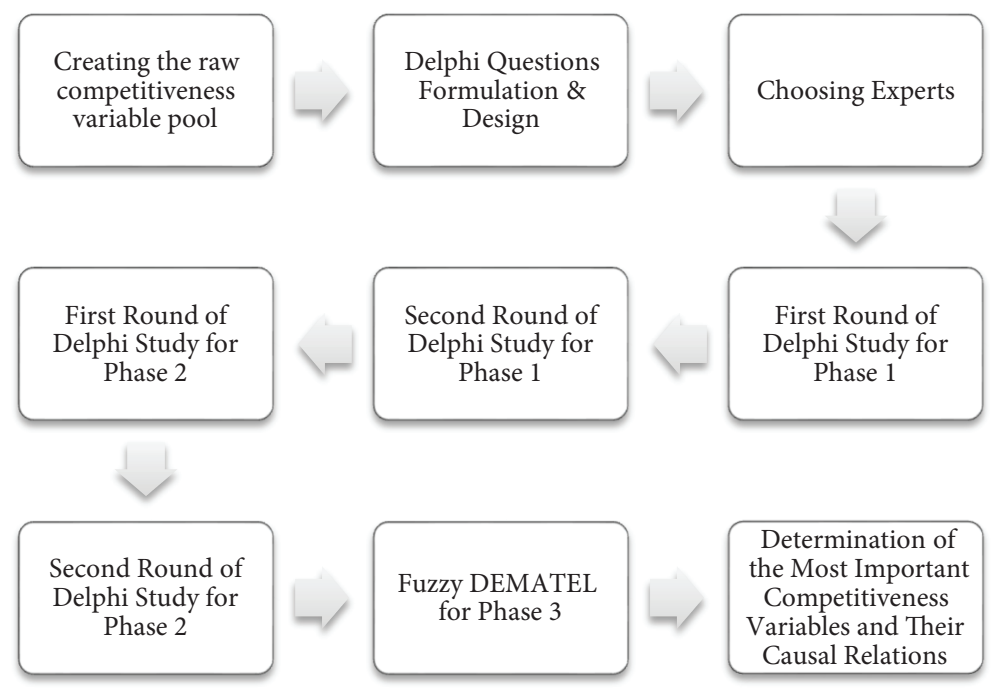

Figure 1. Basic flow diagram of the proposed model

which include ambiguity and imprecision. Delphi method is indubitably a key technique for obtaining expert opinions, and it is used in this study to assess the most important competitiveness variables and enable the usage of the hybrid model.

\section{Materials and methods}

\subsection{Delphi method}

Delphi is a method established by the RAND Corporation that enables the scientific use of expert opinion. The Delphi method is a group technique with controlled feedback to obtain expert opinions through series of intensive surveys (Dalkey \& Helmer, 1963). Subsequent implementations of the technique overcame the barriers to reaching consensus; thus, in its current form, the use of experts to attain a confidential group opinion can be described as a social research technique. This is a way of creating communication among experts, who can provide valuable insights to solve complicated problems (Linstone \& Turoff, 1975).

The Delphi method is a recurrent process. Experts should be asked the same questions at least twice, with feedback from other experts, so that they can reconsider their answers. Since the answers are sent directly to the group coordinator, the participants and answers can be kept anonymous, avoiding any negative effects of personality or status between participating experts. All irrelevant information can be eliminated by the group coordinator, and questions should be formulated in a way to enable the processing of the answers statistically and quantitatively (Landeta, 2006).

\section{Modifications to Delphi method in the proposed model}

Delphi technique continues to be commonly used, although its weaknesses are often criticized. Various studies have proposed methods to overcome these, including the proposed 
hybrid model in this study which aims to create deeper knowledge of the subject investigated through new analysis outputs by integrating the widely-used DEMATEL method into the Delphi method. Since both techniques use expert opinion, they are perfectly compatible.

The five main weaknesses of the classic Delphi technique (Landeta, 2006) are (1) Obtaining basic information only from specialists, (2) Obligation to reach consensus as a method of approaching the truth, (3) Difficulty in controlling the accuracy and reliability of the method, (4) The time required to carry out the work, (5) The potential for experts to act irresponsibly. The proposed method overcomes some of these difficulties as explained below.

A literature review is utilized as the basic information source, along with expert knowledge. In the proposed model, there is no need for the selected experts to brainstorm the variables, as these are obtained through a literature review. If however, experts believe some variables of the studied subject are missing, they can make suggestions in the first phase of the model. In this study, more than 82 articles examining competitiveness variables were examined in order to extract the variables that affect SME competitiveness.

The requirement to reach consensus may lead to the loss of information, and force the participants to reach an involuntarily agreement. For this reason, in the proposed model, there is no requirement for consensus. In order to boost the accuracy and reliability of the method, the experts are required to have deep knowledge of both the studied area and the applied technique in order to make an effective contribution. The proposed method stipulates the criteria that the specialists must meet. The time needed to carry out the work is greatly reduced through the use of online surveys in the first and second phases of the model.

Integrating the DEMATEL method provides no protection against potential irresponsible actions of the experts or reduce the effort required to carry out the work. Experts participating in the surveys need a clear understanding of how the study will benefit themselves and society. In this study, most participating experts (all in Phase 3) are SME managers, and were advised of the potential benefits of redirecting their company policies in the light of the study outputs, and as a result, we observed that the experts showed enthusiasm and serious involvement.

\subsection{Fuzzy DEMATEL method}

\subsubsection{Fuzzy theory}

When deciding on a fuzzy setting, the outcome of the decision is greatly influenced by uncertain subjective judgments. Sources of uncertainty include: unqualified, incomplete and inaccessible information and partial ignorance (Chen and Hwang, 1992). The fuzzy set theory was originally proposed as a mathematical method for representing and handling uncertainty (Zadeh, 1965). In a fuzzy setting, linguistic terms are variables that are not represented by numbers, but resemble natural language phrases (Zadeh, 1975). Fuzzy numbers generally represent linguistic terms, and the most frequently used are triangular fuzzy numbers. In this study, we utilize triangular fuzzy numbers (Table 3) to represent the linguistic terms.

A triangular fuzzy number (TFN) can be defined as a triplet $(a 1, a 2, a 3)$ and the membership function of the fuzzy number $\tilde{\mathrm{A}}$ is defined as: 


$$
\mathrm{f}_{\tilde{A}}(\mathrm{x})=\left\{\begin{array}{c}
0, x<\mathrm{a}_{1} \\
\left(x-\mathrm{a}_{1}\right) /\left(\mathrm{a}_{2}-\mathrm{a}_{1}\right), \mathrm{a}_{1} \leq x \leq \mathrm{a}_{2} \\
\left(\mathrm{a}_{3}-x\right) /\left(\mathrm{a}_{3}-\mathrm{a}_{2}\right), \mathrm{a}_{2}<x \leq \mathrm{a}_{3} \\
0, x>\mathrm{a}_{3}
\end{array}\right.
$$

where $a_{1}, a_{2}$ and $a_{3}$ are real numbers and $a_{1} \leq a_{2} \leq a_{3}$.

Table 3. Triangular fuzzy numbers and linguistic terms

\begin{tabular}{|l|l|}
\hline \multicolumn{1}{|c|}{ Linguistic Terms } & \multicolumn{1}{c|}{ Triangular Fuzzy Numbers } \\
\hline Very high influence $-(\mathrm{VH})$ & $(0.75,1.0,1.0)$ \\
\hline High influence $-(\mathrm{H})$ & $(0.5,0.75,1.0)$ \\
\hline Low influence $-(\mathrm{L})$ & $(0.25,0.5,0.75)$ \\
\hline Very low influence $-(\mathrm{VL})$ & $(0,0.25,0.5)$ \\
\hline No influence - $(\mathrm{No})$ & $(0,0,0.25)$ \\
\hline
\end{tabular}

\subsubsection{DEMATEL method}

The DEMATEL method was originally operated by Geneva Research Center at The Battelle Memorial Institute (Gabus \& Fontela, 1972). DEMATEL is an extensive method for constructing and analyzing a structural model. Cause-and-effect relationships between system elements are formed in DEMATEL, a method used in many fields (Lin \& Wu, 2008). DEMATEL method enables the managers to make strategic decisions in a very specific way. It is constructed using graph theory, and solves problems with visualization (Zhou, Huang, \& Zhang, 2011). In DEMATEL graphs, all the elements are separated into cause and effect groups which allows researchers a clear understanding of the relationship between the elements (Wang \& Chuu, 2004). DEMATEL method makes use of the defined steps below (Wu \& Lee, 2007).

Step 1: Create the initial direct relation matrix. The expert panel evaluates direct impact levels between two system elements by pair-wise comparisons. The direct correlation matrix $\mathrm{Z}=\left[\mathrm{z}_{\mathrm{ij}}\right]_{\mathrm{nxn}}$, shows how factor $\mathrm{i}$ effects factor $\mathrm{j}$ directly. $\mathrm{Z}$ is a non-negative matrix and when $\mathrm{i}=\mathrm{j}$, the main diagonal elements of $z_{i j}$ will be equal to zero.

Step 2: Normalize the initial direct relation matrix. Normalized direct correlation matrix $\mathrm{X}=\left[\mathrm{x}_{\mathrm{ij}}\right]_{\mathrm{nxn}}$ and $0 \leq \mathrm{x}_{\mathrm{ij}} \leq 1$ can be obtained using the formulas (1) and (2). Main diagonal elements will again be equal to zero.

$$
\begin{gathered}
X=s \cdot Z ; \\
s=\frac{1}{\max _{1 \leq i \leq n} \sum_{j=1}^{n} z_{i j}}, \\
i, j=1,2, \ldots, n .
\end{gathered}
$$

Step 3: Obtain the total correlation matrix. The total correlation matrix is acquired through the following equation (3). This matrix reflects the total relation between each element. 


$$
\begin{gathered}
T=X+X^{2}+\ldots+X^{k}=X\left(1+X+X^{2}+\ldots+X^{k-1}\right)(1-X)(1-X)^{-1} ; \\
T=X(1-X)^{-1} .
\end{gathered}
$$

Step 4: Compute sum of the rows and sum of the columns of the total correlation matrix using (5) and (6). R represents the direct and indirect effects of element $\mathrm{i}$ to other elements. Likewise, D summarizes all other elements that are directly and indirectly affected by element j.

$$
\begin{gathered}
T=t_{i j}, \quad i, j=1,2, \ldots, n ; \\
R=\sum_{i=1}^{n} t_{i j} ; \\
D=\sum_{j=1}^{n} t_{i j} .
\end{gathered}
$$

When $i=j, D+R$ shows the effects delivered and taken by element $i$. Thus, the $D+R$ indicator represents the importance level of the element in the overall system. In contrast, $D-R$ indicator displays the effect of element i on the system. In particular, when $D-R$ value is positive, the element is in the cause group and if negative, in the effect group.

Step 5: Create a causal relation diagram. The causal diagram enabling visualization can be drawn by plotting $D+R$ values on $\mathrm{x}$ axis and $D-R$ values on y axis so that the relationship between the factors is visualized. Finally, the net influence matrix which displays the strength of the causal relationships between variables (Khompatraporn \& Somboonwiwat, 2017) is presented as matrix $N_{i j}=t_{i j}-t_{j i}$.

\subsubsection{Fuzzy DEMATEL}

A well-structured defuzzification method often considers that a fuzzy number is characterized by its shape, spread, height, and relative location on the x-axis. Centroid (Center-ofgravity) method is a very common defuzzification method (Yager \& Filev, 1994), however, this method fails to distinguish between two fuzzy numbers with the same crisp value, even though they have different shapes. Thus, we adopt the CFCS (Converting Fuzzy Data into Crisp Scores) method for the defuzzification process, due to its superior crisp scores (Wu \& Lee, 2007). In the CFCS method, the left and right values are calculated by fuzzy minimum and maximum and weighted average, with membership functions used to calculate the total score. When $\tilde{z}_{i j}^{k}=\left(l_{i j}^{k}, m_{i j}^{k}, r_{i j}^{k}\right)$, the fuzzy computation of evaluator $\mathrm{k}(\mathrm{k}=1,2, \ldots, \mathrm{p})$ indicates the influence level of factor $i$ to the factor $j$. The CFCS method is composed of a five-step algorithm, taken from Opricovic and Tzeng (2003), described as below:

Step 1: Conduct normalization

$$
\begin{aligned}
x l_{i j}^{k} & =\left(l_{i j}^{k}-\min l_{i j}^{k}\right) / \Delta_{\min }^{\max } ; \\
x m_{i j}^{k} & =\left(m_{i j}^{k}-\min l_{i j}^{k}\right) / \Delta_{\min }^{\max } ; \\
x r_{i j}^{k} & =\left(r_{i j}^{k}-\min l_{i j}^{k}\right) / \Delta_{\min }^{\max },
\end{aligned}
$$

where $\Delta_{\min }^{\max }=\max r_{i j}^{k}-\min l_{i j}^{k}$. 
Step 2: Calculate left and right normalized values:

$$
\begin{aligned}
& x s_{i j}^{k}=x m_{i j}^{k} /\left(1+x m_{i j}^{k}-x l_{i j}^{k}\right), \\
& x r s_{i j}^{k}=x r_{i j}^{k} /\left(1+x r_{i j}^{k}-x m_{i j}^{k}\right) .
\end{aligned}
$$

Step 3: Calculate total normalized crisp value:

$$
x_{i j}^{k}=\left[x l s_{i j}^{k}\left(1-x l s_{i j}^{k}\right)+x r s_{i j}^{k} x r s_{i j}^{k}\right] /\left[1-x l s_{i j}^{k}+x r s_{i j}^{k}\right] .
$$

Step 4: Calculate crisp values:

$$
z_{i j}^{k}=\min l_{i j}^{k}+x_{i j}^{k} \Delta_{\min }^{\max } .
$$

Step 5: Integrate crisp values:

$$
z_{i j}^{k}=\frac{1}{p}\left(z_{i j}^{1}+z_{i j}^{2}+\ldots+z_{i j}^{p}\right) .
$$

\section{Empirical study and results}

\subsection{Application of the proposed hybrid model}

The management of the questionnaires was based on the general outline of the Delphi study, summarized by Schmidt et al. (2001). As shown in Table 4, the procedure consisted of three phases. Phase 1 involved a comprehensive literature review and brainstorming session with the experts; phase 2 consisted of narrowing down the competitiveness variables; phase 3 involved performing the relationship analysis and ranking the most important variables. Two independent panels were formed, one consisting of 20 academic experts with deep knowledge in competitiveness area, and the other of 20 SME managers operating in the field of textile industry.

The academic experts were chosen from senior faculty members of seven different universities located in Istanbul and Izmir. They were required to either have given taught courses on competitiveness or held a position which involved increasing a SME's business performance. The academic experts worked in either Business Administration or Industrial Engineering departments. The SME managers invited to take a part in the study were required to have at least 20 years of business experience and knowledge of managing a SME in the field of textile industry. These managers were also all from Izmir and Istanbul. The research application from phase 1 to phase 3 took six months in total. We had applied strict selection criteria because quality of a Delphi study is highly depended on the experts' intellectual potential (Radziszewski et al., 2016). Due to the strict selection criteria and the small sample size, the potential use of statistical techniques was limited. The details of each phase are explained below. 
Table 4. Empirical application of the Proposed hybrid model

\begin{tabular}{|c|c|}
\hline $\begin{array}{l}\text { Phase 1: } \\
\text { Literature Review \& } \\
\text { Brainstorming }\end{array}$ & $\begin{array}{l}\text { - Competitiveness variables were gathered from all relevant } \\
\text { competitiveness literature, yielding } 73 \text { items. } \\
\text { - Duplicates or variables that have the same meaning were removed by } \\
\text { SME managers. } \\
\text { - Some variables were filtered and combined resulting in } 60 \text { unique } \\
\text { variables. }\end{array}$ \\
\hline $\begin{array}{l}\text { Phase 2: } \\
\text { Narrowing Down }\end{array}$ & $\begin{array}{l}\text { - Two independent expert panels (academics and SME managers) were } \\
\text { selected. } \\
\text { - The most important competitiveness variables were selected by each } \\
\text { panelist. } \\
\text { - Through two phased questionnaire, competitiveness variables were } \\
\text { reduced to } 15 \text { by natural consensus. }\end{array}$ \\
\hline $\begin{array}{l}\text { Phase 3: } \\
\text { Relationship Analysis \& } \\
\text { Ranking }\end{array}$ & $\begin{array}{l}\text { - SME managers panel conducted relationship analysis using fuzzy } \\
\text { DEMATEL method. } \\
\text { - Results from DEMATEL yielded the relationship analysis among the } \\
\text { variables and their rankings. }\end{array}$ \\
\hline
\end{tabular}

\section{Phase 1: Literature review \& brainstorming}

The gathering of the variables at this stage does not solely depend on the opinion of the experts. Academic studies on the subject together with globally recognized professional studies suggest that a total of 73 variables affect the competitiveness of SMEs. Therefore, the fundamental information related to the variables was gathered from a comprehensive scientific knowledge base. This phase includes two questionnaires in total. SME managers, through the field information, filtered out the variables whose meanings overlapped using questionnaire 1. Questionnaire 1 also solicited expert's suggestions for additional variables not included in the literature review. In the second questionnaire, the revised list of variables was reviewed by the experts. The following 13 variables were eliminated, either deleted or merged with other variables: strategic decision making, firm culture, standardized financial documents, entrepreneurship, lean management, co-opetition, risk management, leadership, on-job training, outsourced training, product technology, firm's innovation capacity and investment for IT.

\section{Phase 2: Narrowing down}

In the second phase, two independent groups of panelists (academics and SME managers) were selected. There are two reasons why the academic panel was not formed until the second phase. The primary reason was that most of the sources of variables were compiled through academic studies, and the secondary reason was the elimination of the variables by the experts working in the field would lead to results that were more adaptable to real life. This phase included two questionnaires, like the first stage. Following the first and second questionnaire, in the third questionnaire the important variables were scored by each panelist using the Likert scale (1-5). Then, after seeing the results of the third questionnaire, the panelists were asked to fill out the forth questionnaire. Following these two surveys, the 15 most important variables were determined through natural consensus. 


\section{Phase 3: Relationship analysis \& ranking}

The panel of SME Managers applied the fuzzy DEMATEL method for the 15 variables. The relationship analysis and the ranking of the selected variables were obtained through the application of the fuzzy DEMATEL method. Among 60 variables, 15 were chosen as the most important competitiveness variables for SME's in the textile industry. There were two reasons for limiting the number of variables to 15 . First, only 15 scored higher than 4.0, which was midway between the values "Important" and "Very Important" in questionnaires 3 and 4. In questionnaire 3, 19 variables reached an average higher than 4.0, but in questionnaire 4 this number was only 15. All variables that scored slightly less than 4.0 in questionnaire 3, dropped their score in questionnaire 4 (e.g. the investment for R\&D averaged 3.97 in questionnaire 3 , but fell to 3.89 in questionnaire 4).

These results increased our confidence in limiting the number to 15 and confirmed we had not missed any important variables that scored very close to our threshold. The second reason was the required rigorous effort when applying DEMATEL method. Increasing the number of questions would increase the potential of errors in a DEMATEL questionnaire. Conducting DEMATEL with 15 variables resulted in a $15 \times 15$ matrix, minus the main diagonals, thus yielding a total of 210 questions for SME managers.

\subsection{Data analysis and results}

The results obtained from Phase 3 represents crucial information for SME managers, especially those in the textile industry. 15 most important competitiveness variables were labeled as V1 (Product Quality), V2 (Product Delivery), V3 (Product Cost), V4 (Product Flexibility), V5 (Product Design), V6 (Product Service), V7 (Communication with Customers), V8 (Degree of Customer Orientation), V9 (Product Pricing), V10 (Customer Satisfaction), V11 (Proactiveness), V12 (Product Innovation), V13 (Knowledge Acquisition), V14 (Employee Skills), V15 (Open-mindedness). The data from each individual assessment was aggregated into the initial direct relation matrix (Table 5) using the CFCS method. The fuzzy linguistic data was converted into crisp values using the formulas (7)-(14) for each assessment. The values given in Table 5 must first be normalized before creating the total relation matrix.

To produce the normalized direct relation matrix (Table 6), formulas (1) and (2) were used. $(D+R)$ and $(D-R)$ values cannot be calculated without a total relation matrix, and the values in Table 6 were necessary to create the total relation matrix. As explained in the methodology section, next step was to create the total relation matrix. Applying formula (3) created the total relation matrix (Table 7). Total relation matrix uses formula (3) to create D values and formula (4) to create R values. $\mathrm{D}$ and $\mathrm{R}$ values were obtained by formulas (4), (5) and (6). The values given in Table 7 were used to calculate $(D+R)$ and $(D-R)$ datasets. Table 8 was created using the net influence matrix calculation as introduced in Step 5 of DEMATEL method. The values of Table 8 show the strength of the causal relations of the variables. In order to map the causal relation diagram (Figure 2), (D+R) and (D-R) datasets obtained from Table 7 were used. The arrows on Figure 2 represent only the crucial relationships, which are higher than a certain threshold value $(0.100$, twice the average). As seen in Figure 2, the cause group variables consist of V1, V2, V3, V4, V5, V11, V13, V14, and V15. The effect 
group variables consist of V6, V7, V8, V9, V10 and V12. The detailed explanation of every variable presented on Figure 2 are discussed in the subsequent section.

Table 5. Initial direct relation matrix

\begin{tabular}{|c|c|c|c|c|c|c|c|c|c|c|c|c|c|c|c|}
\hline Z & V1 & V2 & V3 & V4 & V5 & V6 & V7 & V8 & V9 & V10 & V11 & V12 & V13 & V14 & V15 \\
\hline V1 & 0.000 & 0.333 & 0.934 & 0.567 & 0.500 & 0.600 & 0.867 & 0.767 & 0.934 & 0.934 & 0.567 & 0.567 & 0.400 & 0.800 & 0.433 \\
\hline V2 & 0.333 & 0.000 & 0.400 & 0.500 & 0.333 & 0.533 & 0.733 & 0.367 & 0.500 & 0.834 & 0.367 & 0.367 & 0.400 & 0.433 & 0.200 \\
\hline V3 & 0.767 & 0.300 & 0.000 & 0.500 & 0.733 & 0.433 & 0.200 & 0.433 & 0.967 & 0.800 & 0.633 & 0.600 & 0.333 & 0.433 & 0.200 \\
\hline V4 & 0.667 & 0.567 & 0.767 & 0.000 & 0.567 & 0.400 & 0.333 & 0.567 & 0.633 & 0.500 & 0.500 & 0.700 & 0.567 & 0.567 & 0.467 \\
\hline V5 & 0.600 & 0.667 & 0.833 & 0.667 & 0.000 & 0.433 & 0.367 & 0.400 & 0.767 & 0.667 & 0.633 & 0.733 & 0.500 & 0.567 & 0.400 \\
\hline V6 & 0.200 & 0.266 & 0.367 & 0.233 & 0.266 & 0.000 & 0.633 & 0.733 & 0.366 & 0.800 & 0.433 & 0.267 & 0.567 & 0.533 & 0.367 \\
\hline V7 & 0.467 & 0.333 & 0.200 & 0.433 & 0.533 & 0.567 & 0.000 & 0.734 & 0.367 & 0.733 & 0.533 & 0.533 & 0.667 & 0.433 & 0.333 \\
\hline V8 & 0.600 & 0.400 & 0.233 & 0.467 & 0.600 & 0.700 & 0.800 & 0.000 & 0.533 & 0.733 & 0.567 & 0.600 & 0.600 & 0.433 & 0.400 \\
\hline V9 & 0.767 & 0.200 & 0.533 & 0.267 & 0.300 & 0.566 & 0.400 & 0.567 & 0.000 & 0.800 & 0.433 & 0.433 & 0.367 & 0.466 & 0.200 \\
\hline V10 & 0.533 & 0.200 & 0.500 & 0.300 & 0.633 & 0.667 & 0.800 & 0.800 & 0.500 & 0.000 & 0.433 & 0.633 & 0.400 & 0.500 & 0.300 \\
\hline V11 & 0.500 & 0.467 & 0.633 & 0.567 & 0.733 & 0.600 & 0.567 & 0.667 & 0.667 & 0.633 & 0.000 & 0.800 & 0.667 & 0.666 & 0.400 \\
\hline V12 & 0.733 & 0.333 & 0.600 & 0.633 & 0.834 & 0.367 & 0.433 & 0.567 & 0.700 & 0.600 & 0.733 & 0.000 & 0.466 & 0.533 & 0.333 \\
\hline V13 & 0.500 & 0.300 & 0.433 & 0.567 & 0.700 & 0.500 & 0.567 & 0.600 & 0.467 & 0.567 & 0.533 & 0.633 & 0.000 & 0.533 & 0.600 \\
\hline V14 & 0.800 & 0.733 & 0.533 & 0.700 & 0.767 & 0.600 & 0.533 & 0.633 & 0.533 & 0.567 & 0.667 & 0.700 & 0.633 & 0.000 & 0.700 \\
\hline V15 & 0.667 & 0.300 & 0.333 & 0.467 & 0.600 & 0.400 & 0.467 & 0.533 & 0.200 & 0.467 & 0.567 & 0.533 & 0.567 & 0.667 & 0.000 \\
\hline
\end{tabular}

Table 6. Normalized direct relation matrix

\begin{tabular}{|c|c|c|c|c|c|c|c|c|c|c|c|c|c|c|c|}
\hline X & V1 & V2 & V3 & V4 & V5 & V6 & V7 & V8 & V9 & V10 & V11 & V12 & V13 & V14 & V15 \\
\hline V1 & 0.000 & 0.036 & 0.101 & 0.062 & 0.054 & 0.065 & 0.094 & 0.083 & 0.101 & 0.101 & 0.062 & 0.062 & 0.043 & 0.087 & 0.047 \\
\hline V2 & 0.036 & 0.000 & 0.043 & 0.054 & 0.036 & 0.058 & 0.080 & 0.040 & 0.054 & 0.091 & 0.040 & 0.040 & 0.043 & 0.047 & 0.022 \\
\hline V3 & 0.083 & 0.033 & 0.000 & 0.054 & 0.080 & 0.047 & 0.022 & 0.047 & 0.105 & 0.087 & 0.069 & 0.065 & 0.036 & 0.047 & 0.022 \\
\hline V4 & 0.072 & 0.062 & 0.083 & 0.000 & 0.062 & 0.043 & 0.036 & 0.062 & 0.069 & 0.054 & 0.054 & 0.076 & 0.062 & 0.062 & 0.051 \\
\hline V5 & 0.065 & 0.072 & 0.091 & 0.072 & 0.000 & 0.047 & 0.040 & 0.043 & 0.083 & 0.072 & 0.069 & 0.080 & 0.054 & 0.062 & 0.043 \\
\hline V6 & 0.022 & 0.029 & 0.040 & 0.025 & 0.029 & 0.000 & 0.069 & 0.080 & 0.040 & 0.087 & 0.047 & 0.029 & 0.062 & 0.058 & 0.040 \\
\hline V7 & 0.051 & 0.036 & 0.022 & 0.047 & 0.058 & 0.062 & 0.000 & 0.080 & 0.040 & 0.080 & 0.058 & 0.058 & 0.072 & 0.047 & 0.036 \\
\hline V8 & 0.065 & 0.043 & 0.025 & 0.051 & 0.065 & 0.076 & 0.087 & 0.000 & 0.058 & 0.080 & 0.062 & 0.065 & 0.065 & 0.047 & 0.043 \\
\hline V9 & 0.083 & 0.022 & 0.058 & 0.029 & 0.033 & 0.062 & 0.043 & 0.062 & 0.000 & 0.087 & 0.047 & 0.047 & 0.040 & 0.051 & 0.022 \\
\hline V10 & 0.058 & 0.022 & 0.054 & 0.033 & 0.069 & 0.072 & 0.087 & 0.087 & 0.054 & 0.000 & 0.047 & 0.069 & 0.043 & 0.054 & 0.033 \\
\hline V11 & 0.054 & 0.051 & 0.069 & 0.062 & 0.080 & 0.065 & 0.062 & 0.072 & 0.072 & 0.069 & 0.000 & 0.087 & 0.072 & 0.072 & 0.043 \\
\hline V12 & 0.080 & 0.036 & 0.065 & 0.069 & 0.091 & 0.040 & 0.047 & 0.062 & 0.076 & 0.065 & 0.080 & 0.000 & 0.051 & 0.058 & 0.036 \\
\hline V13 & 0.054 & 0.033 & 0.047 & 0.062 & 0.076 & 0.054 & 0.062 & 0.065 & 0.051 & 0.062 & 0.058 & 0.069 & 0.000 & 0.058 & 0.065 \\
\hline V14 & 0.087 & 0.080 & 0.058 & 0.076 & 0.083 & 0.065 & 0.058 & 0.069 & 0.058 & 0.062 & 0.072 & 0.076 & 0.069 & 0.000 & 0.076 \\
\hline V15 & 0.072 & 0.033 & 0.036 & 0.051 & 0.065 & 0.043 & 0.051 & 0.058 & 0.022 & 0.051 & 0.062 & 0.058 & 0.062 & 0.072 & 0.000 \\
\hline
\end{tabular}


Table 7. Total relation matrix

\begin{tabular}{|c|c|c|c|c|c|c|c|c|c|c|c|c|c|c|c|}
\hline T & V1 & V2 & V3 & V4 & V5 & V6 & V7 & V8 & V9 & V10 & V11 & V12 & V13 & V14 & V15 \\
\hline V1 & 0.330 & 0.254 & 0.390 & 0.333 & 0.379 & 0.363 & 0.399 & 0.418 & 0.425 & 0.479 & 0.366 & 0.386 & 0.329 & 0.384 & 0.263 \\
\hline V2 & 0.261 & 0.151 & 0.246 & 0.241 & 0.261 & 0.263 & 0.292 & 0.275 & 0.279 & 0.350 & 0.250 & 0.264 & 0.241 & 0.254 & 0.172 \\
\hline V3 & 0.347 & 0.211 & 0.247 & 0.277 & 0.341 & 0.291 & 0.277 & 0.323 & 0.371 & 0.396 & 0.315 & 0.329 & 0.268 & 0.294 & 0.199 \\
\hline V4 & 0.352 & 0.248 & 0.336 & 0.240 & 0.341 & 0.300 & 0.304 & 0.350 & 0.353 & 0.384 & 0.317 & 0.354 & 0.305 & 0.321 & 0.236 \\
\hline V5 & 0.359 & 0.266 & 0.355 & 0.318 & 0.296 & 0.316 & 0.320 & 0.348 & 0.379 & 0.416 & 0.342 & 0.370 & 0.310 & 0.333 & 0.238 \\
\hline V6 & 0.240 & 0.174 & 0.233 & 0.209 & 0.248 & 0.202 & 0.275 & 0.303 & 0.257 & 0.337 & 0.250 & 0.248 & 0.251 & 0.257 & 0.185 \\
\hline V7 & 0.297 & 0.202 & 0.248 & 0.256 & 0.305 & 0.288 & 0.241 & 0.334 & 0.290 & 0.367 & 0.289 & 0.305 & 0.288 & 0.277 & 0.203 \\
\hline V8 & 0.336 & 0.226 & 0.275 & 0.280 & 0.336 & 0.324 & 0.345 & 0.287 & 0.332 & 0.398 & 0.316 & 0.336 & 0.304 & 0.301 & 0.226 \\
\hline V9 & 0.309 & 0.175 & 0.265 & 0.223 & 0.263 & 0.272 & 0.265 & 0.300 & 0.235 & 0.354 & 0.262 & 0.276 & 0.241 & 0.263 & 0.176 \\
\hline V10 & 0.316 & 0.197 & 0.287 & 0.252 & 0.325 & 0.308 & 0.330 & 0.352 & 0.315 & 0.307 & 0.290 & 0.325 & 0.271 & 0.293 & 0.206 \\
\hline V11 & 0.361 & 0.255 & 0.345 & 0.319 & 0.382 & 0.343 & 0.351 & 0.386 & 0.380 & 0.425 & 0.289 & 0.389 & 0.338 & 0.353 & 0.247 \\
\hline V12 & 0.364 & 0.229 & 0.326 & 0.308 & 0.371 & 0.302 & 0.318 & 0.356 & 0.365 & 0.399 & 0.344 & 0.289 & 0.300 & 0.323 & 0.227 \\
\hline V13 & 0.325 & 0.215 & 0.293 & 0.289 & 0.344 & 0.301 & 0.317 & 0.344 & 0.323 & 0.377 & 0.311 & 0.338 & 0.240 & 0.308 & 0.244 \\
\hline V14 & 0.407 & 0.294 & 0.353 & 0.348 & 0.403 & 0.360 & 0.366 & 0.402 & 0.385 & 0.441 & 0.374 & 0.397 & 0.351 & 0.304 & 0.289 \\
\hline V15 & 0.319 & 0.202 & 0.264 & 0.262 & 0.313 & 0.272 & 0.288 & 0.315 & 0.276 & 0.342 & 0.294 & 0.307 & 0.279 & 0.302 & 0.169 \\
\hline
\end{tabular}

Table 8. Net influence matrix

\begin{tabular}{|c|c|c|c|c|c|c|c|c|c|c|c|c|c|c|c|}
\hline $\mathrm{T}$ & $\mathrm{V} 1$ & $\mathrm{~V} 2$ & $\mathrm{~V} 3$ & $\mathrm{~V} 4$ & $\mathrm{~V} 5$ & $\mathrm{~V} 6$ & $\mathrm{~V} 7$ & $\mathrm{~V} 8$ & $\mathrm{~V} 9$ & $\mathrm{~V} 10$ & $\mathrm{~V} 11$ & $\mathrm{~V} 12$ & $\mathrm{~V} 13$ & V14 & V15 \\
\hline V1 & 0.000 & & & & & & & & & & & & & & \\
\hline V2 & 0.007 & & & & & & & & & & & & & & \\
\hline V3 & -0.043 & -0.035 & & & & & & & & & & & & & \\
\hline V4 & 0.019 & 0.007 & 0.059 & & & & & & & & & & & & \\
\hline V5 & -0.020 & 0.006 & 0.014 & -0.023 & & & & & & & & & & & \\
\hline V6 & -0.123 & -0.089 & -0.058 & -0.092 & -0.068 & & & & & & & & & & \\
\hline V7 & -0.102 & -0.089 & -0.029 & -0.048 & -0.015 & 0.013 & & & & & & & & & \\
\hline V8 & -0.083 & -0.049 & -0.048 & -0.070 & -0.012 & 0.022 & 0.011 & & & & & & & & \\
\hline V9 & -0.116 & -0.104 & -0.106 & -0.130 & -0.116 & 0.015 & -0.025 & -0.032 & & & & & & & \\
\hline V10 & -0.163 & -0.153 & -0.109 & -0.132 & -0.091 & -0.029 & -0.036 & -0.046 & -0.038 & & & & & & \\
\hline V11 & -0.005 & 0.005 & 0.029 & 0.001 & 0.040 & 0.094 & 0.062 & 0.070 & 0.118 & 0.135 & & & & & \\
\hline V12 & -0.022 & -0.035 & -0.004 & -0.046 & 0.001 & 0.055 & 0.013 & 0.019 & 0.088 & 0.074 & -0.044 & & & & \\
\hline V13 & -0.004 & -0.025 & 0.025 & -0.016 & 0.034 & 0.050 & 0.029 & 0.040 & 0.082 & 0.105 & -0.027 & 0.038 & & & \\
\hline V14 & 0.023 & 0.040 & 0.058 & 0.027 & 0.070 & 0.103 & 0.089 & 0.101 & 0.122 & 0.148 & 0.021 & 0.075 & 0.043 & & \\
\hline V15 & 0.057 & 0.030 & 0.065 & 0.026 & 0.076 & 0.087 & 0.086 & 0.089 & 0.100 & 0.136 & 0.047 & 0.080 & 0.036 & 0.013 & 0.000 \\
\hline
\end{tabular}

To sum up, three phased hybrid Delphi and fuzzy DEMATEL model was conducted with academic experts and SME managers. In phase 1 of the proposed model, 60 competitiveness variables were filtered from the competitiveness variable pool. In phase 2 , the 15 most important competitiveness variables were identified. In phase 3, the causal relations were acquired from the causal relation diagram. In addition to identifying the cause and effect groups and relations of the variables, $\mathrm{D}+\mathrm{R}$ values were used to reveal the importance level of each vari- 


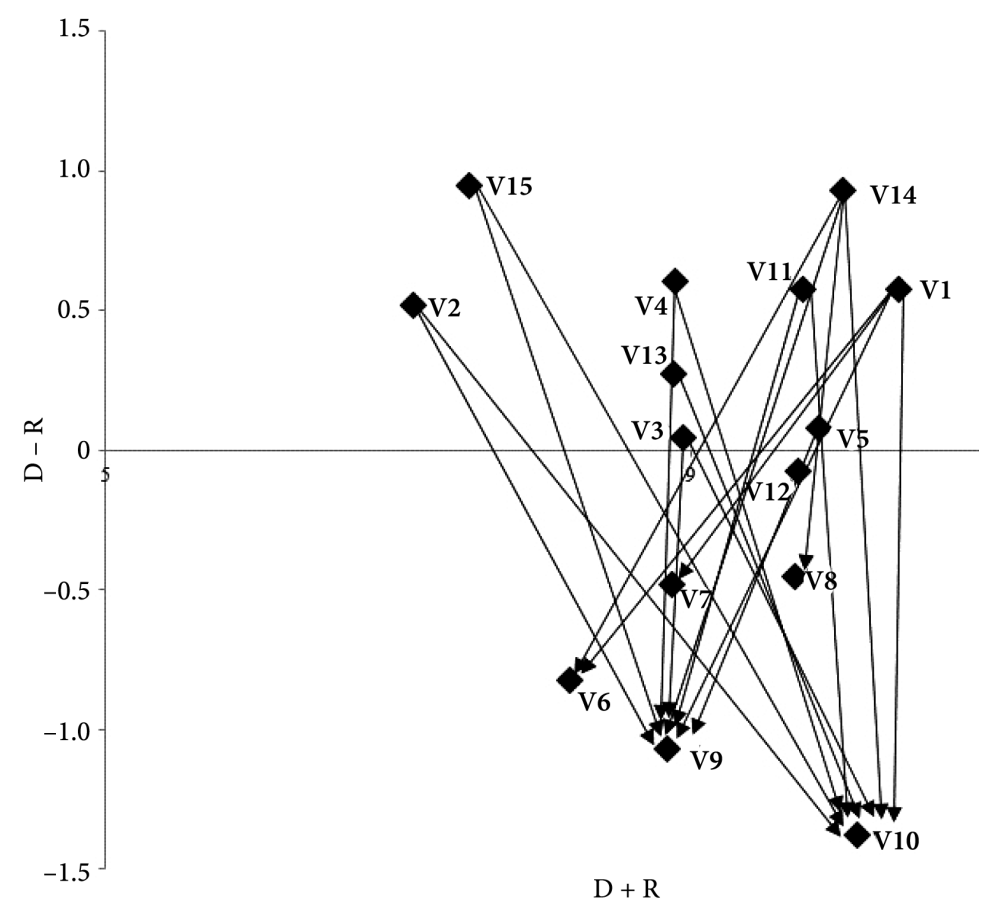

Figure 2. Causal relation diagram

able, enabling the ranking step. The most important variable that affects SME competitiveness was found to be Product Quality (V1), followed (in order of importance) by V10-V14-V5V11-V12-V8-V3-V4-V13-V7-V9-V6-V15-V2. The ranking of the cause group variables is V1-V14-V5-V11-V3-V4-V13-V15-V2, and for the effect group, V10-V12-V8-V7-V9-V6.

\subsection{Discussion}

The chosen variables were categorized under four areas as production, marketing, innovation and organizational learning. The results support the idea that organizational learning is a crucial emerging topic for creating business competitiveness and strategy policies (Pérez López, Manuel Montes Peón, \& José Vazquez Ordás, 2005). In phase 3, the causal relation diagram (Figure 1) can produce valuable information for making strategic decisions. To improve the variables in the effect group, SME managers need to firstly consider the cause group variables. Thus, in order to increase competitive power of a SME, they need to prioritize variables that have high influence and high intensity of relation, as these are more difficult to assess and enhance.

One serious potential misconception when interpreting the critical data given in Figure 2 would be to underestimate the importance of the variables with low $\mathrm{D}+\mathrm{R}$ values. Although it is true that low $\mathrm{D}+\mathrm{R}$ value would mean less important compared to other variables, these 15 variables were identified as the most important competitiveness variables and the different 
impact of each should be thoroughly analysed. The causal relation diagram in Figure 2 shows the importance levels of each variable, which supports the identification of the cause and effect relationships of the most important variables. According to the results, Open-mindedness is the most influencing variable, followed by Employee Skills. However, the importance level of Open-mindedness is significantly lower than Employee Skills, which holds a strategic position, as both a very high influencer and one of the most important variables. Therefore, Employee Skills is a key variable for SME managers to focus on. Product Quality holds a similar position as most important variable and a high influencer variable. Product Delivery is another high influencer variable; however, it is perceived as the least important of the 15 variables. Before making any improvements to Product Delivery, managers would be advised to focus on another influencer variable with high importance such as Product Quality.

Product Flexibility and Knowledge Acquisition both have mediocre importance; however, the former, as the third most influencer variable, has a higher influence level than the latter. Proactiveness is a valuable variable like Product Quality with high influence and importance levels. Product Cost, Product Design and Product Innovation are almost in the neutral area - and can hardly be described as an influencer or influenced variable. Product Cost and Product Design falls slightly in the cause group whereas Product Innovation falls slightly in the effect group. Product Design and Product Innovation are perceived to have almost same importance level with both having higher importance than Product Cost. Customer Satisfaction is the second most important variable and the most influenced variable in the effect group. To increase customer satisfaction levels, SME managers should focus first on the most influencer variables such as Employee Skills or Product Quality. Product Pricing is one of the least important variables and second most influenced variable. Pricing strategy is frequently categorised under marketing and has various dependencies on other variables such as quality or cost (L. Leonidou, C. Leonidou, Fotiadis, \& Zeriti, 2013). Product Service, just as Product Pricing falls into same category of less important and most influenced variables. Communication with Customers and Degree of Customer Orientation are both in the effect group, however neither variables are greatly influenced by other variables such as Customer Satisfaction. Degree of Customer Orientation has a high importance level, and exclusively focusing on other variables would not significantly affect this variable. Therefore, to increase their customer orientation performance, SME managers first need to focus specifically on this variable, before the influencer variables.

Unlike many of the previous studies, Product Cost was not found to be the most important variable affecting competitiveness; both variables that represent innovation (V11 and V12) scored higher. This might imply that SMEs are willing to invest in innovation to increase their competitive power (Yamin et al., 1997). SME managers should aim to build learning organizations, to nurture new ideas and support proactive activities, and to encourage appropriate risk-taking. Product Quality, Customer Satisfaction and Employee Skills form the three most important variables. Total Quality Management (TQM) is a highly appropriate customer focused, employee involved and quality centered method, as it involves the continuous improvement of these three key variables. Thus, SME managers should consider implementing TQM strategies to increase their firm's competitive power. Also, long-term relationships with the customers should be emphasized, taking into consideration customer differentiation, in order to provide high quality services, ensuring customer loyalty. 
The three most influencing variables are Open-mindedness, Employee Skills and Product Flexibility. As these are the most difficult to change, SME managers or human resources department should make efforts to hire open-minded and skillful employees (Wanto \& Suryasaputra, 2012). Personality tests can be conducted in the hiring process to reveal employee characteristics. To attract those with the required qualities, SME managers can implement performance rewarding or profit sharing programs to enhance employee benefits. Previous studies suggest that Product Flexibility and Employee Skills are directly related, thus, hiring skillful employees enables flexible production. Suitably skilled employees are better able to respond to environmental changes, allowing the firm to be more proactive. Customer Satisfaction, Product Pricing and Product Service are the variables that are most influenced. Evidently, Customer Satisfaction is influenced by the cause group variables. Cause group variables such as Product Quality and Product Flexibility play a crucial role in determining product pricing policies, in line with marketing studies that support the view that the price is determined by the market, rather than by the firm itself. Product service no longer follows predetermined standard procedures, due to the dramatic increase in product variety, and the indeterminate nature of customers. Finally, the importance of Product Flexibility, Product Delivery, and Proactiveness underlines the need for SME managers to focus on logistics and responsiveness.

The research implications for this study include contributions to competitiveness literature, by addressing the need for the holistic approach in the field and offering a methodology for the analysis of competitiveness variables (Singh et al., 2008). The competitiveness literature lacks holistic approach to factors affecting competitiveness of SMEs, thus, the SME competitiveness variable pool was created to enable the gathering all of the variables, whether widely known or emerging, in the production field. Scholars and practitioners were able to examine the competitiveness variables holistically through the usage of hybrid model. The competitiveness variable pool is a tool for all SME managers in the production field to consider and reassess the factors that affect the SME competitiveness. Thus, the approach considers new and emerging variables that are attracting the attention of scholars and practitioners globally. This paper reveals the most important 15 variables that are relevant to SME competitiveness in the textile industry. Managers may aim find that a focus on these variables will increase their firm's competitive power and will gain potentially valuable insight from the causal diagram obtained from the hybrid model. With a clear understanding of the influenced and influencer variables, managers can make strategic decisions on how to address their firm's competitive weaknesses. The results obtained from the proposed model can be an effective guide for SME managers in the development of competitiveness improvement policies.

\section{Conclusions}

This study suggests eight managerial implications. Five are deducted directly from the fuzzy DEMATEL results, and remaining three are our recommendations to managers operating in the field of textile industry based on the results of our model. Employee Skills is a high influencer and one of the key variables for focus and improvements to Product Quality should be another priority. To increase customer satisfaction, influencer variables, such as these should 
be addressed first. A good pricing strategy is not influenced by Product Cost as much as Product Quality. Influencer variables have no considerable impact on the Degree of Customer Orientation. Therefore, it is crucial for managers to implement TQM strategies to increase their firm's competitive power. Conducting personality and skill tests before hiring, and implementing performance rewarding systems or programs that focus to improve Employee Skills should be a high priority for SME managers. Lastly, managers should be educated about the importance of logistics and responsiveness.

There are also three research implications in this study. Firstly, the competitiveness variable pool, in which all of the variables that affect competitiveness of SME's in the production field are accumulated, can form the basis for future studies. Secondly, using holistic approach in the analysis of competitiveness variables contributes to addressing the gap in the competitiveness literature. Thirdly, this paper presents a hybrid model that investigates the variables that affect SME competitiveness, as well as their degree of importance, in the textile industry. The hybrid model offers a platform to examine and analyze these variables by focusing on the opinions of valuable academic experts and SME managers.

We acknowledge that applying Delphi method has its own limitations and issues; however, the new modifications introduced in our study are designed to reduce these limitations. For the DEMATEL method, we use fuzzy method to further enhance the decision making process of SME managers. Using precise numerical values for human judgment and decisions can cause a lack of clarity, introducing fuzzy logic is essential in respect to issues inherently characterised by ambiguity and imprecision. However, although an appropriate method, fuzzy logic for DEMATEL can never be entirely problem free when dealing with human decisions. The competitiveness variable pool and the model framework can be applied to other sectors in the production field but it should be noted that the results obtained in this specific study apply only to the textile industry in Turkey. Nevertheless, in future studies, this framework can be used in different country or sector contexts for the purposes of comparison.

\section{Acknowledgements}

We are grateful for the support of all valuable SME managers and academicians who took part in this research.

\section{Funding}

This study was not funded by any organization.

\section{Author contributions}

CT was responsible for the design, development, data analysis and data interpretation. CC and $\mathrm{YK}$ were responsible for design, development and data interpretation. CT wrote the first draft, CC and YK helped in the correction and forming the final draft. 


\section{Disclosure statement}

We have no conflicts of interest to disclose.

\section{References}

Acquaah, M., \& Yasai-Ardekani, M. (2008). Does the implementation of a combination competitive strategy yield incremental performance benefits? A new perspective from a transition economy in Sub-Saharan Africa. Journal of Business Research, 61(4), 346-354. https://doi.org/10.1016/j.jbusres.2007.06.021

Aragón-Correa, J. A., García-Morales, V. J., \& Cordón-Pozo, E. (2007). Leadership and organizational learning's role on innovation and performance: Lessons from Spain. Industrial Marketing Management, 36(3), 349-359. https://doi.org/10.1016/j.indmarman.2005.09.006

Avella, L., Fernandez, E., \& Vazquez, C. J. (1998). Taxonomy of the manufacturing strategies of large Spanish industrial companies. International Journal of Production Research, 36(11), 3113-3134. https://doi.org/10.1080/002075498192328

Bayraktar, C. A., Hancerliogullari, G., Cetinguc, B., \& Calisir, F. (2017). Competitive strategies, innovation, and firm performance: an empirical study in a developing economy environment. Technology Analysis \& Strategic Management, 29(1), 38-52. https://doi.org/10.1080/09537325.2016.1194973

Bhatt, G. D., \& Grover, V. (2005). Types of information technology capabilities and their role in competitive advantage: an empirical study. Journal of Management Information Systems, 22(2), 253-277. https://doi.org/10.1080/07421222.2005.11045844

Bontis, N., Crossan, M. M., \& Hulland, J. (2002). Managing an organizational learning system by aligning stocks and flows. Journal of Management Studies, 39(4), 437-469.

https://doi.org/10.1111/1467-6486.t01-1-00299

Cagliano, R., Acur, N., \& Boer, H. (2005). Patterns of change in manufacturing strategy configurations. International Journal of Operations \& Production Management, 25(7), 701-718. https://doi.org/10.1108/01443570510605108

Calantone, R. J., Cavusgil, S. T., \& Zhao, Y. (2002). Learning orientation, firm innovation capability, and firm performance. Industrial Marketing Management, 31(6), 515-524. https://doi.org/10.1016/S0019-8501(01)00203-6

Carneiro, A. (2000). How does knowledge management influence innovation and competitiveness? Journal of Knowledge Management, 4(2), 87-98. https://doi.org/10.1108/13673270010372242

Cetindamar, D., \& Kilitcioglu, H. (2013). Measuring the competitiveness of a firm for an award system. Competitiveness Review: An International Business Journal, 23(1), 7-22. https://doi.org/10.1108/10595421311296597

Chao, C. A., \& Chandra, A. (2012). Impact of owner's knowledge of information technology (IT) on strategic alignment and IT adoption in US small firms. Journal of Small Business and Enterprise Development, 19(1), 114-131. https://doi.org/10.1108/14626001211196433

Chari, S., Balabanis, G., Robson, M. J., \& Slater, S. (2017). Alignments and misalignments of realized marketing strategies with administrative systems: Performance implications. Industrial Marketing Management, 63, 129-144. https://doi.org/10.1016/j.indmarman.2016.11.002

Chen, S. J., \& Hwang, C. L. (1992). Fuzzy ranking methods. In Fuzzy multiple attribute decision making (pp. 101-288). Springer Berlin Heidelberg. https://doi.org/10.1007/978-3-642-46768-4_4

Cohen, J. F., \& Olsen, K. (2013). The impacts of complementary information technology resources on the service-profit chain and competitive performance of South African hospitality firms. International Journal of Hospitality Management, 34, 245-254. https://doi.org/10.1016/j.ijhm.2013.04.005 
Dalkey, N., \& Helmer, O. (1963). An experimental application of the Delphi method to the use of experts. Management Science, 9(3), 458-467. https://doi.org/10.1287/mnsc.9.3.458

Fang, S. C., Wang, M. C., \& Chen, P. C. (2017). The influence of knowledge networks on a firm's innovative performance. Journal of Management \& Organization, 23(1), 22-45. https://doi.org/10.1017/jmo.2016.32

Frohlich, M. T., \& Dixon, J. R. (2001). A taxonomy of manufacturing strategies revisited. Journal of Operations Management, 19(5), 541-558. https://doi.org/10.1016/S0272-6963(01)00063-8

Gabus, A., \& Fontela, E. (1972). World problems, an invitation to further thought within the framework of DEMATEL. Battelle Geneva Research Center, Geneva, Switzerland.

Gál, A. N. (2010). Competitiveness of small and medium sized enterprises-a possible analytical framework. Hungarian Electronic Journal of Science, HEJ: ECO-100115-A.

García-Morales, V. J., Jiménez-Barrionuevo, M. M., \& Gutiérrez-Gutiérrez, L. (2012). Transformational leadership influence on organizational performance through organizational learning and innovation. Journal of Business Research, 65(7), 1040-1050. https://doi.org/10.1016/j.jbusres.2011.03.005

Global Competitiveness Index. (2017). The Global Competitiveness Report (2017-2018). World Economic Forum, Geneva, Switzerland.

Gonzalez, M. E., Quesada, G., Mueller, R., \& Mora-Monge, C. A. (2004). QFD strategy house: an innovative tool for linking marketing and manufacturing strategies. Marketing Intelligence \& Planning, 22(3), 335-348. https://doi.org/10.1108/02634500410536911

Guzmán, G. M., Gutiérrez, J. S., Cortes, J. G., \& Ramírez, R. G. (2012). Measuring the competitiveness level in furniture SMEs of Spain. International Journal of Economics and Management Sciences, 1(11), 09-19.

Intracen SME Competitiveness Grid. (2016). SME Competitiveness Outlook 2016. International Trade Centre, Geneva, Switzerland.

Jiménez-Jiménez, D., \& Sanz-Valle, R. (2011). Innovation, organizational learning, and performance. Journal of Business Research, 64(4), 408-417. https://doi.org/10.1016/j.jbusres.2010.09.010

Joshi, D., Nepal, B., Rathore, A. P. S., \& Sharma, D. (2013). On supply chain competitiveness of Indian automotive component manufacturing industry. International Journal of Production Economics, 143(1), 151-161. https://doi.org/10.1016/j.ijpe.2012.12.023

Kalkan, A., Erdil, O., \& Çetinkaya, Ö. (2011). The relationships between firm size, prospector strategy, architecture of information technology and firm performance. Procedia-Social and Behavioral Sciences, 24, 854-869. https://doi.org/10.1016/j.sbspro.2011.09.114

Kast, F. E., \& Rosenzweig, J. E. (1972). General systems theory: Applications for organization and management. Academy of Management Journal, 15(4), 447-465. https://doi.org/10.2307/255141

Kathuria, R. (2000). Competitive priorities and managerial performance: a taxonomy of small manufacturers. Journal of Operations Management, 18(6), 627-641.

https://doi.org/10.1016/S0272-6963(00)00042-5

Kim, E., Nam, D. I., \& Stimpert, J. L. (2004). Testing the applicability of Porter's generic strategies in the digital age: A study of Korean cyber malls. Journal of Business Strategies, 21(1), 19.

Khompatraporn, C., \& Somboonwiwat, T. (2017). Causal factor relations of supply chain competitiveness via fuzzy DEMATEL method for Thai automotive industry. Production Planning \& Control, 28(6-8), 538-551. https://doi.org/10.1080/09537287.2017.1309713

Lai, F., Zhao, X., \& Wang, Q. (2006). The impact of information technology on the competitive advantage of logistics firms in China. Industrial Management \& Data Systems, 106(9), 1249-1271. https://doi.org/10.1108/02635570610712564

Landeta, J. (2006). Current validity of the Delphi method in social sciences. Technological Forecasting and Social Change, 73(5), 467-482. https://doi.org/10.1016/j.techfore.2005.09.002 
Leonidou, L. C., Leonidou, C. N., Fotiadis, T. A., \& Zeriti, A. (2013). Resources and capabilities as drivers of hotel environmental marketing strategy: Implications for competitive advantage and performance. Tourism Management, 35, 94-110. https://doi.org/10.1016/j.tourman.2012.06.003

Leonidou, L. C., Katsikeas, C. S., \& Samiee, S. (2002). Marketing strategy determinants of export performance: a meta-analysis. Journal of Business Research, 55(1), 51-67.

https://doi.org/10.1016/S0148-2963(00)00133-8

Lin, C. J., \& Wu, W. W. (2008). A causal analytical method for group decision-making under fuzzy environment. Expert Systems with Applications, 34(1), 205-213. https://doi.org/10.1016/j.eswa.2006.08.012

Linstone, H. A., \& Turoff, M. (Eds.). (1975). The Delphi method: techniques and applications (Vol. 29). Reading, MA: Addison-Wesley.

Linton, G., \& Kask, J. (2017). Configurations of entrepreneurial orientation and competitive strategy for high performance. Journal of Business Research, 70, 168-176.

https://doi.org/10.1016/j.jbusres.2016.08.022

Lorsuwanrat, T. (2010). Management tools. Bangkok: Z Probe Printing.

Mandal, P., \& Bagchi, K. (2016). Strategic role of information, knowledge and technology in manufacturing industry performance. Industrial Management \& Data Systems, 116(6), 1259-1278. https://doi.org/10.1108/IMDS-07-2015-0297

Mao, H., Liu, S., Zhang, J., \& Deng, Z. (2016). Information technology resource, knowledge management capability, and competitive advantage: the moderating role of resource commitment. International Journal of Information Management, 36(6), 1062-1074.

https://doi.org/10.1016/j.ijinfomgt.2016.07.001

Martin, S. L., Javalgi, R. G., \& Cavusgil, E. (2017). Marketing capabilities, positional advantage, and performance of born global firms: Contingent effect of ambidextrous innovation. International Business Review, 26(3), 527-543. https://doi.org/10.1016/j.ibusrev.2016.11.006

Melville, N., Kraemer, K., \& Gurbaxani, V. (2004). Information technology and organizational performance: An integrative model of IT business value. MIS Quarterly, 28(2), 283-322. https://doi.org/10.2307/25148636

Miller, J. G., \& Roth, A. V. (1994). A taxonomy of manufacturing strategies. Management Science, 40(3), 285-304. https://doi.org/10.1287/mnsc.40.3.285

Minniti, M., \& Bygrave, W. (1999). The microfoundations of entrepreneurship. Entrepreneurship: Theory and Practice, 23(4), 41-41. https://doi.org/10.1177/104225879902300403

Ollo-López, A., \& Aramendía-Muneta, M. E. (2012). ICT impact on competitiveness, innovation and environment. Telematics and Informatics, 29(2), 204-210. https://doi.org/10.1016/j.tele.2011.08.002

Opricovic, S., \& Tzeng, G. H. (2003). Defuzzification within a multicriteria decision model. International Journal of Uncertainty, Fuzziness and Knowledge-Based Systems, 11(05), 635-652. https://doi. org/10.1142/S0218488503002387

Perez, J. R. \& Pablos, P. O. (2003). Knowledge managemant and organizational competitveness: a framework for human capital analysis. Journal of Knowledge Management, 7(3), 82-91. https://doi.org/10.1108/13673270310485640

Pérez López, S., Manuel Montes Peón, J., \& José Vazquez Ordás, C. (2005). Organizational learning as a determining factor in business performance. The Learning Organization, 12(3), 227-245. https://doi.org/10.1108/09696470510592494

Pertusa-Ortega, E. M., Molina-Azorín, J. F., \& Claver-Cortés, E. (2009). Competitive strategies and firm performance: A comparative analysis of pure, hybrid and "stuck-in-the-middle" strategies in Spanish firms. British Journal of Management, 20(4), 508-523.

https://doi.org/10.1111/j.1467-8551.2008.00597.x 
Powell, T. C., \& Dent-Micallef, A. (1997). Information technology as competitive advantage: The role of human, business, and technology resources. Strategic Management Journal, 375-405. https://doi.org/10.1002/(SICI)1097-0266(199705)18:5<375::AID-SMJ876>3.0.CO;2-7

Powers, T. L., \& Hahn, W. (2004). Critical competitive methods, generic strategies, and firm performance. International Journal of Bank Marketing, 22(1), 43-64. https://doi.org/10.1108/02652320410514924

Radziszewski, P., Nazarko, J., Vilutiene, T., Dębkowska, K., Ejdys, J., Gudanowska, A., Halicka, K., Kilon, J., Kononiuk, A., Kowalski, K. J., Król, J. B., Nazarko, L., \& Sarnowski, M. (2016). Future trends in road technologies development in the context of environmental protection. The Baltic Journal of Road and Bridge Engineering, 11(2), 160-168. https://doi.org/10.3846/bjrbe.2016.19

Resurreccion, P. F. (2012). Performance management and compensation as drivers of organization competitiveness: The Philippine perspective. International Journal of Business and Social Science, 3(21).

Rhee, M., \& Mehra, S. (2006). Aligning operations, marketing, and competitive strategies to enhance performance: An empirical test in the retail banking industry. Omega, 34(5), 505-515. https://doi.org/10.1016/j.omega.2005.01.017

Rose, R. C., Kumar, N., \& Ibrahim, H. I. (2008). The effect of manufacturing strategy on organizational performance. Performance Improvement, 47(1), 18-25. https://doi.org/10.1002/pfi.175

Rundh, B. (2003). Rethinking the international marketing strategy: new dimensions in a competitive market. Marketing Intelligence \& Planning, 21(4), 249-257. https://doi.org/10.1108/02634500310480130

Salavou, H., Baltas, G., \& Lioukas, S. (2004). Organisational innovation in SMEs: the importance of strategic orientation and competitive structure. European Journal of Marketing, 38(9/10), 1091-1112. https://doi.org/10.1108/03090560410548889

Santos-Vijande, M. L., López-Sánchez, J. Á., \& Trespalacios, J. A. (2012). How organizational learning affects a firm's flexibility, competitive strategy, and performance. Journal of Business Research, 65(8), 1079-1089. https://doi.org/10.1016/j.jbusres.2011.09.002

Schmidt, R., Lyytinen, K., Keil, M., \& Cule, P. (2001). Identifying software project risks: An international Delphi study. Journal of Management Information Systems, 17(4), 5-36.

0https://doi.org/10.1080/07421222.2001.11045662

Singh, R. K., Garg, S. K., \& Deshmukh, S. G. (2008). Strategy development by SMEs for competitiveness: a review. Benchmarking: An International Journal, 15(5), 525-547. https://doi.org/10.1108/14635770810903132

Sirikrai, S. B., \& Tang, J. C. (2006). Industrial competitiveness analysis: Using the analytic hierarchy process. The Journal of High Technology Management Research, 17(1), 71-83. https://doi.org/10.1016/j. hitech.2006.05.005

Siu, W. S., Fang, W., \& Lin, T. (2004). Strategic marketing practices and the performance of Chinese small and medium-sized enterprises (SMEs) in Taiwan. Entrepreneurship \& Regional Development, 16(2), 161-178. https://doi.org/10.1080/08985620410001677862

Song, Z. H. (2015). Organizational learning, absorptive capacity, imitation and innovation: Empirical analyses of 115 firms across China. Chinese Management Studies, 9(1), 97-113. https://doi. org/10.1108/CMS-05-2014-0092

Street, C. T., \& Cameron, A. F. (2007). External relationships and the small business: A review of small business alliance and network research. Journal of Small Business Management, 45(2), 239-266. https://doi.org/10.1111/j.1540-627X.2007.00211.x

Sweeney, M. T., \& Szwejczewski, M. (1996). The search for generic manufacturing strategies in the UK engineering industry. Manufacturing Strategy: Operations Strategy in a Global Context (pp. 659-664). London Business School, London. 
Szerb, L., \& Ulbert, J. (2009). The examination of the competitiveness in the Hungarian SME sector: A firm level analysis. Acta Polytechnica Hungarica, 6(3), 105-123.

Tian, Y., Jia, Y., \& Malik, S. A. (2010). Taxonomy of manufacturing strategies: A worldwide perspective. International Conference on Management and Service Science (pp. 1-4). Wuhan. https://doi.org/10.1109/ICMSS.2010.5578443

Wang, R. C., \& Chuu, S. J. (2004). Group decision-making using a fuzzy linguistic approach for evaluating the flexibility in a manufacturing system. European Journal of Operational Research, 154(3), 563-572. https://doi.org/10.1016/S0377-2217(02)00729-4

Wanto, H. S., \& Suryasaputra, R. (2012). The effect of organizational culture and organizational learning towards the competitive strategy and company performance (case study of East Java SMEs in Indonesia: Food and beverage industry). Information Management and Business Review, 4(9), 467.

Wattanapruttipaisan, T. (2002). SME subcontracting as a bridgehead to competitiveness: An assessment of supply-side capabilities and demand-side requirements. Asia-Pacific Development Journal, 9(1), 65-87.

Wu, C. S., Lin, C. T., \& Lee, C. (2010). Competitive marketing strategies decision-making based on marketing resources and capabilities: evidence from the hospitality industry in Taiwan. Journal of Quality Assurance in Hospitality \& Tourism, 11(4), 219-238. https://doi.org/10.1080/1528008X.2010.504163

Wu, W. W., \& Lee, Y. T. (2007). Developing global managers' competencies using the fuzzy DEMATEL method. Expert Systems with Applications, 32(2), 499-507. https://doi.org/10.1016/j.eswa.2005.12.005

Yager, R. R., \& Filev, D. P. (1994). Essentials of fuzzy modeling and control. New York.

Yamin, S., Mavondo, F., Gunasekaran, A., \& Sarros, J. C. (1997). A study of competitive strategy, organisational innovation and organisational performance among Australian manufacturing companies. International Journal of Production Economics, 52(1-2), 161-172. https://doi.org/10.1016/S0925-5273(96)00104-1

Yeo, R. K. (2007). Identifying the competitive sword: Learning to be cutting-edge for organizational development. Business Strategy Series, 9(1), 30-36. https://doi.org/10.1108/17515630810850091

Zadeh, L. A. (1965). Fuzzy logic and its applications. New York, NY, USA.

Zadeh, L. A. (1975). The concept of a linguistic variable and its application to approximate reasoning I. Information Sciences, 8(3), 199-249. https://doi.org/10.1016/0020-0255(75)90036-5

Ziegler, A., \& Nogareda, J. S. (2009). Environmental management systems and technological environmental innovations: Exploring the causal relationship. Research Policy, 38(5), 885-893. https://doi.org/10.1016/j.respol.2009.01.020

Zhao, X., Sum, C. C., Qi, Y., Zhang, H., \& Lee, T. S. (2006). A taxonomy of manufacturing strategies in China. Journal of Operations Management, 24(5), 621-636. https://doi.org/10.1016/j.jom.2005.07.003

Zhou, D., Kautonen, M., Wang, H., \& Wang, L. (2017). How to interact with knowledge-intensive business services: A multiple case study of small and medium manufacturing enterprises in China. Journal of Management \& Organization, 23(2), 297-318. https://doi.org/10.1017/jmo.2016.23

Zhou, Q., Huang, W., \& Zhang, Y. (2011). Identifying critical success factors in emergency management using a fuzzy DEMATEL method. Safety Science, 49(2), 243-252.

https://doi.org/10.1016/j.ssci.2010.08.005 